\title{
Article \\ Expert Consensus on the Contraindications and Cautions of Foam Rolling-An International Delphi Study
}

\author{
Katja Martina Bartsch ${ }^{1}$, Christian Baumgart ${ }^{2}{ }^{\oplus}$, Jürgen Freiwald ${ }^{2}{ }^{\oplus}$, Jan Wilke ${ }^{3}{ }^{\circ}$, Gunda Slomka ${ }^{4}$, \\ Sascha Turnhöfer ${ }^{5}$, Christoph Egner ${ }^{5}$, Matthias W. Hoppe ${ }^{6}$, Werner Klingler ${ }^{7,8, *}$ and Robert Schleip ${ }^{8,9,10,11}$ (D) \\ 1 Department of Sport Science and Sport (DSS), FAU Erlangen-Nürnberg, 91054 Erlangen, Germany; \\ katja.kb.bartsch@fau.de \\ 2 Department of Movement and Training Science, University of Wuppertal, 42119 Wuppertal, Germany; \\ baumgart@uni-wuppertal.de (C.B.); freiwald@uni-wuppertal.de (J.F.) \\ 3 Institute of Occupational, Social and Environmental Medicine, Goethe University Frankfurt, \\ 60487 Frankfurt/Main, Germany; wilke@sport.uni-frankfurt.de \\ 4 Stiftungsuniversität Hildesheim, 31141 Hildesheim, Germany; slomka@uni-hildesheim.de \\ 5 Diploma Hochschule, 37242 Bad Sooden-Allendorf, Germany; nasakg@aol.com (S.T.); \\ christoph.egner@diploma.de (C.E.) \\ 6 Movement and Training Science, Leipzig University, 04109 Leipzig, Germany; matthias.hoppe@uni-leipzig.de \\ 7 SRH Hospital, 72488 Sigmaringen, Germany \\ 8 Experimental Anaesthesiology, Ulm University, 89069 Ulm, Germany; robert.schleip@tum.de \\ 9 Department of Sports Medicine and Health Promotion, Friedrich Schiller University Jena, \\ 07749 Jena, Germany \\ check for \\ updates \\ Citation: Bartsch, K.M.; Baumgart, \\ C.; Freiwald, J.; Wilke, J.; Slomka, G.; \\ 10 Fascia Research Group, Experimental Anesthesiology, Ulm University, 89069 Ulm, Germany \\ 11 Conservative and Rehabilitative Orthopedics, Department of Sport and Health Sciences, Technical University \\ of Munich, 80809 Munich, Germany \\ * Correspondence: werner.klingler@srh.de; Tel.: +49-(0)-7571-100-2331
} Turnhöfer, S.; Egner, C.; Hoppe, M.W.; Klingler, W.; Schleip, R. Expert Consensus on the Contraindications and Cautions of Foam Rolling-An International Delphi Study. J. Clin. Med. 2021, 10, 5360. https://doi.org/ $10.3390 /$ jcm 10225360

Academic Editors: Tomasz Halski and Ersilia Lucenteforte

Received: 9 September 2021

Accepted: 10 November 2021

Published: 17 November 2021

Publisher's Note: MDPI stays neutral with regard to jurisdictional claims in published maps and institutional affiliations.

Copyright: (c) 2021 by the authors. Licensee MDPI, Basel, Switzerland. This article is an open access article distributed under the terms and conditions of the Creative Commons Attribution (CC BY) license (https:/ / creativecommons.org/licenses/by/ $4.0 /)$.

\begin{abstract}
Background: Foam rolling is a type of self-massage using tools such as foam or roller sticks. However, to date, there is no consensus on contraindications and cautions of foam rolling. A methodological approach to narrow that research gap is to obtain reliable opinions of expert groups. The aim of the study was to develop experts' consensus on contraindications and cautions of foam rolling by means of a Delphi process. Methods: An international three-round Delphi study was conducted. Academic experts, defined as having (co-) authored at least one PubMedlisted paper on foam rolling, were invited to participate. Rounds 1 and 2 involved generation and rating of a list of possible contraindications and cautions of foam rolling. In round 3, participants indicated their agreement on contraindications and cautions for a final set of conditions. Consensus was evaluated using a priori defined criteria. Consensus on contraindications and cautions was considered as reached if more than $70 \%$ of participating experts labeled the respective item as contraindication and contraindication or caution, respectively, in round 3. Results: In the final Delphi process round, responses were received from 37 participants. Panel participants were predominantly sports scientists $(n=21)$, physiotherapists $(n=6)$, and medical professionals $(n=5)$. Consensus on contraindications was reached for open wounds (73\% agreement) and bone fractures $(84 \%)$. Consensus on cautions was achieved for local tissue inflammation (97\%), deep vein thrombosis (97\%), osteomyelitis (94\%), and myositis ossificans (92\%). The highest impact/severity of an adverse event caused by contraindication/cautions was estimated for bone fractures, deep vein thrombosis, and osteomyelitis. Discussion: The mechanical forces applied through foam rolling can be considered as potential threats leading to adverse events in the context of the identified contraindications and cautions. Further evaluations by medical professionals as well as the collection of clinical data are needed to assess the risks of foam rolling and to generate guidance for different applications and professional backgrounds.
\end{abstract}

Keywords: myofascial; fascia; self-myofascial release; massage 


\section{Background}

Foam rolling is a type of self-massage using soft or rigid foam rolls [1-4]. Despite its broad application and popularity in medicine and sports [5,6], a gap of knowledge exists regarding contraindications and cautions, when aiming to integrate foam rolling as a therapeutic or training tool into practice [7]. In fact, a large body of evidence describes the effects and mechanisms of foam rolling [4,8-11] but less is known regarding contraindications and cautions $[12,13]$. Table 1 shows a PubMed literature search that underlines this lack of research.

Table 1. PubMed literature search on contraindications and cautions of foam rolling. The search was limited to human subjects and performed on 2 November 2020.

\begin{tabular}{|c|c|c|}
\hline Search Steps & Search Terms & Search Results \\
\hline 1 & $\begin{array}{l}\text { "foam roll", "foam rolling", or "foam roller" } \\
\text { combined by Boolean logic ("OR") }\end{array}$ & 146 \\
\hline 2 & $\begin{array}{c}\text { "contraindication", " caution*", "precaution*", "red flag*", } \\
\text { or "yellow flag*" } \\
\text { combined by Boolean logic (“OR") }\end{array}$ & 75.613 \\
\hline 1 AND 2 & combined by Boolean logic (“AND”) & 1 \\
\hline
\end{tabular}

Guidelines advise clinicians to evaluate the underlying pathology by checking for alarm signals during physical examination and assessment of the patient's medical history [14-16]. Such alarm signals can be labelled as contraindications and cautions. It is recommended that the existence of generally accepted contraindications and cautions (in addition to the related information of health service providers about these) contributes to an improved client assessment by clinicians [17].

As indicated by Table 1, a literature search, revealed only one paper that comments on the clinical standards and contraindications/cautions within the broader context of foam rolling [13]. The authors of that study considered the therapeutic massage literature [18-24] to produce an initial list of potential contraindications and cautions as empirical evidence is scarce. While said paper is commenting on the contraindications and cautions of roller massage practices, the list of contraindications and cautions can serve as a valuable starting point for more focused investigations.

Besides the collection of clinical data as the gold standard model, obtaining a reliable opinion consensus of experts represents another way of gaining insight into potential contraindications and cautions [25]. In view of the scarcity of papers targeting contraindications and cautions of foam rolling, our study aimed to provide initial data on expert opinions using a Delphi process, which has been widely used across numerous disciplines to seek expert opinions in an iterative structured manner [26-28].

\section{Methods}

\subsection{Ethics and General Approach}

The international 3-round Delphi study was conducted between February and May 2021. Ethics approval was obtained from the local ethic committee (Ethics Committee of the Diploma University of Applied Sciences, Bad Sooden-Allendorf, Germany, Ref. no. EB 1003). All participants provided written informed consent. The study was registered with the German Clinical Trials Register (DRKS, number DRKS00025347).

The Delphi method is a standardized technique to interactively and iteratively discuss, form and pool the opinions of several individuals $[25,29]$. The optimal methodological approach defines several specific criteria for reaching consensus a priori [30,31]. Throughout the process, anonymity between participants as well as controlled feedback constitute key features of the method [32]. 


\subsection{Recruitment of Panel Members}

Academic experts were invited to participate in the study. Inclusion criterion for being considered as an academic expert was the publication of at least one peer-reviewed paper on foam rolling as first author or co-author. Previous Delphi studies on contraindications and risks of therapies and interventions achieved consensus with 30 participants [26,33]. Therefore, the authors aimed to have at least 30 respondents for each round. As administered and recommended by prior research [34,35], publicly available bibliographic information from our initial PubMed search (Table 1) was used to identify academic experts. The 146 sources found by the PubMed search were evaluated through a title/abstract screening conducted by three of the authors. Thirty-six records were excluded because of lacking foam rolling content. Furthermore, 8 relevant articles from reviews/meta-analyses and 1 reference through hand search were manually added, leading to a total number 119 eligible sources/articles. The most important criteria for inclusion were an indication of actual experience of the authors/experts with foam rolling in addition to a demonstrated ability to participate in a written discussion in English language about it. Exclusion criteria included lack of any publicly available written material from the expert related to foam rolling, and non-responsiveness in relation to our written invitation. Figure 1 gives an overview of the identification process of relevant publications.

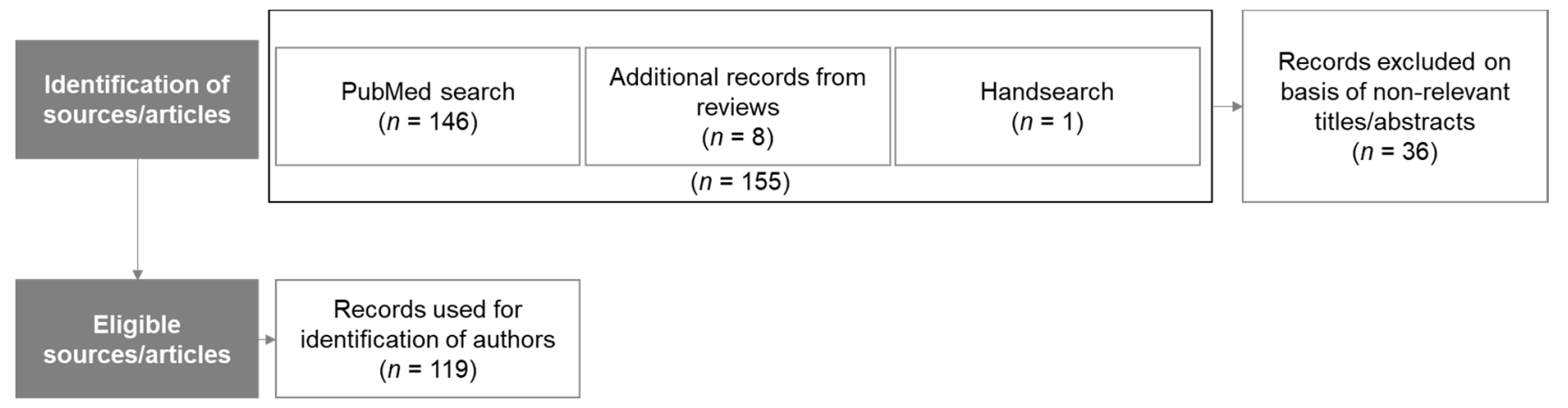

Figure 1. Overview of selection process for relevant publications.

All authors (including co-authors) of the 119 records were documented, which resulted in a total of 396 names. Then, the Internet was searched to obtain contact data of the said 396 authors. Figure 2 shows an overview of the search results. Experts were contacted and invited to take part in the Delphi process via email and online contact forms and social networks with a description of the study goal and process. No additional screening as for potential conflicts of interest or a representative composition of age, gender, nationalities and professions was conducted.

\subsubsection{Delphi Process Rounds and Agreement}

The present study included a preparatory phase as well as three rounds of the actual Delphi process (see Figure 3).

\subsubsection{Preparatory Phase}

Survey development and refinement of the research question was conducted by the Study Steering Group. This group consisted of the study researchers, who met at key stages to discuss and make decisions on protocol design, participant recruitment, data analysis, and study conduct. The Study Steering Group compiled and discussed all participant comments after each round. This group consisted of 10 academic researchers of which 5 members had published peer reviewed articles themselves within the field of foam rolling and 4 used foam rolling regularly in their therapeutic work. All group members were primarily located in Germany. Potential conflicts of interest are declared below. 
A literature search was performed in order to obtain an initial list of potential contraindications and cautions for foam rolling. Participants were identified and contacted as described above.

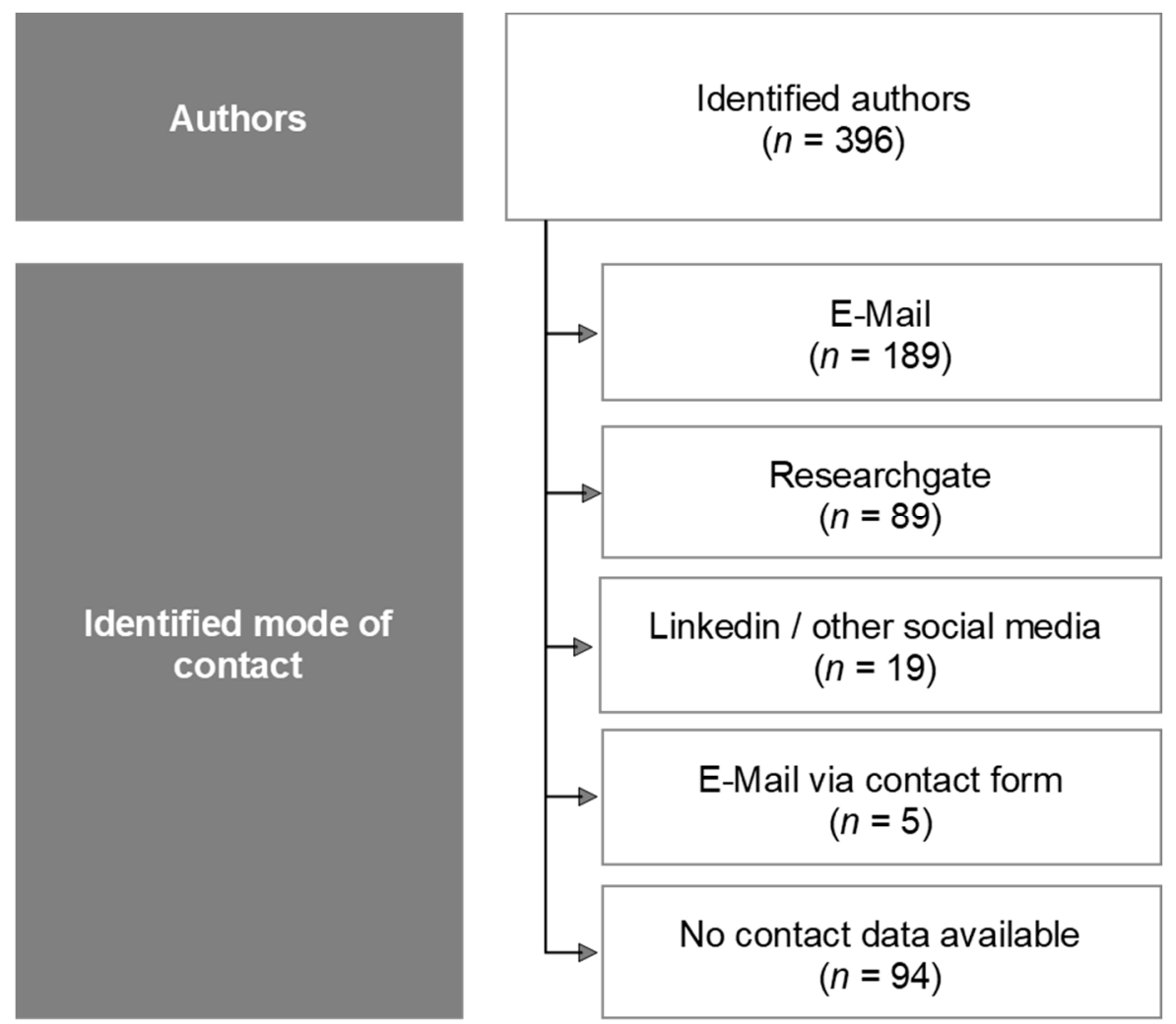

Figure 2. Overview of possible authors/academic experts and contact information.

\begin{tabular}{|c|c|c|c|}
\hline $\begin{array}{l}\text { PRE-PHASE } \\
\text { - Definition of } \\
\text { research question } \\
\text { - Literature research } \\
\text { for initial evaluation } \\
\text { of research question } \\
\text { - Identification of } \\
\text { experts }\end{array}$ & $\begin{array}{l}\text { DELPHI ROUND } 1 \\
\text { - Closed questions: } \\
\text { evaluation of } \\
\text { findings from initial } \\
\text { evaluation } \\
\text { - Open questions: } \\
\text { collection of further } \\
\text { contra-indications \& } \\
\text { cautions }\end{array}$ & $\begin{array}{l}\text { DELPHI ROUND } 2 \\
\text { - Before round 2: } \\
\text { Participants receive } \\
\text { results from Delphi } \\
\text { round } 1 \\
\text { - Closed questions: } \\
\text { evaluation of all } \\
\text { findings from initial } \\
\text { evaluation and } \\
\text { Delphi round } 1\end{array}$ & $\begin{array}{l}\text { DELPHI ROUND } 3 \\
\text { - Before round } 3 \text { : } \\
\text { Participants receive } \\
\text { results from Delphi } \\
\text { round } 2 \\
\text { - Closed questions: } \\
\text { evaluation of all } \\
\text { findings from Delphi } \\
\text { round } 2\end{array}$ \\
\hline
\end{tabular}

Figure 3. Rounds of the Delphi process.

\subsubsection{Delphi Process Round 1}

In round 1, the initial list of contraindications and cautions obtained from the literature was presented to the experts. Participants were asked to rate whether they agreed that the respective line item has to be considered as contraindication/caution on a 6-point Likert scale $(1=$ strongly disagree, $6=$ strongly agree). Participants had the option to give a short explanation of their rating in open text boxes.

Previous studies have used the first round of a 3-round Delphi process to brainstorm for important factors using open questions [36-38]. Therefore, the possibility for experts to brainstorm further possible contraindications and cautions in an open question format was added and no distinction between contraindications and cautions in round 1 was made. In 
this study, the terms contraindication and caution were defined as follows: relating to foam rolling, a contraindication was defined as a condition or factor that makes foam rolling inadvisable. Contraindications can be absolute (i.e., life threatening) or relative (i.e., higher risk of complications in which benefits may outweigh risks). A caution was defined as a condition that increases the risk for a serious short- or long-term adverse reaction. It can furthermore be defined as a "cautionary or warning symptom that warrants consideration of a need for screening". For both contraindications and cautions of foam rolling, the context as the person's age, gender, medical history etc., have to be considered [39].

After a 10-day answer period, results were evaluated by the Study Steering Group and provided to the participants. Participants were asked to read the results from round 1 before the next survey round.

\subsubsection{Delphi Process Round 2}

In round 2, the synthesized contraindications and cautions were evaluated in a closed question format by the participating experts (Table 2).

Table 2. Conditions to be rated throughout Delphi process rounds 1-3.

\begin{tabular}{|c|c|c|c|}
\hline Item & Round 1 & Round 2 & Round 3 \\
\hline 1 & Abnormal sensations (e.g., numbness) & Abnormal sensations (e.g., numbness) & Local tissue inflammation \\
\hline 2 & $\begin{array}{l}\text { Hypertension (with consolation by MD } \\
\text { and controlled) }\end{array}$ & $\begin{array}{l}\text { Hypertension (with consolation by MD } \\
\text { and controlled) }\end{array}$ & Open wounds \\
\hline 3 & Hypertension (uncontrolled) & Hypertension (uncontrolled) & Bone fracture \\
\hline 4 & Diabetes & Diabetes & Myositis ossificans \\
\hline 5 & $\begin{array}{l}\text { Systemic conditions (e.g., metabolic } \\
\text { syndrome/syndrome X) }\end{array}$ & $\begin{array}{l}\text { Systemic conditions (e.g., metabolic } \\
\text { syndrome/syndrome X) }\end{array}$ & Deep vein thrombosis \\
\hline 6 & $\begin{array}{l}\text { Chronic pain conditions (e.g., } \\
\text { Rheumatoid Arthritis) }\end{array}$ & $\begin{array}{l}\text { Chronic pain conditions (e.g., } \\
\text { Rheumatoid Arthritis) }\end{array}$ & Osteomyelitis \\
\hline 7 & $\begin{array}{l}\text { Connective tissue disorders (e.g., } \\
\text { Marfan syndrome) }\end{array}$ & $\begin{array}{l}\text { Connective tissue disorders (e.g., } \\
\text { Marfan syndrome) }\end{array}$ & \\
\hline 8 & Pregnancy (without consultation by MD) & Pregnancy (without consultation by MD) & \\
\hline 9 & Pregnancy (after consultation by MD) & Pregnancy (after consultation by MD) & \\
\hline 10 & $\begin{array}{l}\text { Inability to position body or perform } \\
\text { foam rolling }\end{array}$ & $\begin{array}{l}\text { Inability to position body or perform } \\
\text { foam rolling }\end{array}$ & \\
\hline 11 & Sensitivity to pressure & Sensitivity to pressure & \\
\hline 12 & Extreme discomfort felt by patient & Extreme discomfort felt by patient & \\
\hline 13 & $\begin{array}{l}\text { Medications that may alter a } \\
\text { person's sensation }\end{array}$ & $\begin{array}{l}\text { Medications that may alter a } \\
\text { person's sensation }\end{array}$ & \\
\hline 14 & $\begin{array}{l}\text { Use of blood thinners or medications that } \\
\text { modify touch/pressure sensitivity }\end{array}$ & $\begin{array}{l}\text { Use of blood thinners or medications that } \\
\text { modify touch/pressure sensitivity }\end{array}$ & \\
\hline 15 & Bleeding disorders (e.g., Hemophilia) & Bleeding disorders (e.g., Hemophilia) & \\
\hline 16 & Young children, older individuals & Young children, older individuals & \\
\hline 17 & $\begin{array}{l}\text { Skin rash, open wounds, blisters, local } \\
\text { tissue inflammation }\end{array}$ & Hematoma, bruises & \\
\hline 18 & $\begin{array}{l}\text { Acute infection (viral or bacterial), fever, or } \\
\text { contagious condition }\end{array}$ & Skin rashes, scrapes, blisters & \\
\hline 19 & Bony prominences/regions & Local tissue inflammation, open wounds & \\
\hline 20 & Bone fracture or myositis ossificans & $\begin{array}{l}\text { Acute systemic infection (viral or bacterial), } \\
\text { fever, or contagious condition }\end{array}$ & \\
\hline 21 & Recent injury or surgery & Lymphedema & \\
\hline
\end{tabular}


Table 2. Cont.

\begin{tabular}{|c|c|c|c|}
\hline Item & Round 1 & Round 2 & Round 3 \\
\hline 22 & Scoliosis or spinal deformity & Muscle strain/muscle tear & \\
\hline 23 & Severe scoliosis or spinal deformity & DOMS (delayed onset muscle soreness) & \\
\hline 24 & Osteoporosis & Bony prominences/regions & \\
\hline 25 & Osteopenia & Bone fracture or myositis ossificans & \\
\hline 26 & $\begin{array}{l}\text { Neurologic conditions resulting in loss or } \\
\text { altered sensation (e.g., Multiple Sclerosis) }\end{array}$ & Recent injury or surgery & \\
\hline 27 & $\begin{array}{c}\text { Acute or severe cardiac, liver or } \\
\text { kidney disease }\end{array}$ & Scoliosis or spinal deformity & \\
\hline 28 & Peripheral vascular insufficiency or disease & Severe scoliosis or spinal deformity & \\
\hline 29 & Deep vein thrombosis or osteomyelitis & Osteoporosis & \\
\hline 30 & Varicose Veins & Osteopenia & \\
\hline 31 & Cancer or malignancy & $\begin{array}{l}\text { Neurologic conditions resulting in loss or } \\
\text { altered sensation (e.g., Multiple Sclerosis) }\end{array}$ & \\
\hline 32 & & $\begin{array}{l}\text { Acute traumata, psychiatric illness not } \\
\text { well controlled }\end{array}$ & \\
\hline 33 & & $\begin{array}{c}\text { Acute or severe cardiac, liver or } \\
\text { kidney disease }\end{array}$ & \\
\hline 34 & & Peripheral vascular insufficiency or disease & \\
\hline 35 & & Deep vein thrombosis or osteomyelitis & \\
\hline 36 & & Varicose Veins & \\
\hline 37 & & Cancer or malignancy & \\
\hline 38 & & Substance abuse (e.g., alcohol, drugs) & \\
\hline
\end{tabular}

Previous Delphi studies have used the second round of a 3-round Delphi process to narrow down the original list from round 1 by using pre-defined criteria for dropping items, thereby reducing the list to a manageable size [32,36-38]. The same approach was applied by asking participants to rate whether they agreed that the respective line item had to be considered as contraindication/caution on a 6-point Likert scale $(1=$ strongly disagree, $6=$ strongly agree). Participants had the opportunity to provide a short explanation of their rating but no possibility to add new contraindications or cautions. Identical to round 1, participants did not distinguish between contraindications and cautions-both were treated the same.

Defining consensus criteria a priori is considered a quality indicator for Delphi studies. A systematic review on the definition of consensus found that the most common definition for consensus was percent agreement, with the median threshold for the determination of consensus being $75 \%$ (range: $50-97 \%$ ) [32]. Therefore, it was predefined that only contraindications / cautions that at least $75 \%$ of participating experts agreed with (Likert score 5 or more) were further considered for round 3 of the Delphi process.

Statistical and qualitative results of round 2 were provided to all participants before the start of round 3. As in the previous round, participants were asked to read the results before answering the survey of round 3 .

\subsubsection{Delphi Process Round 3}

In round 3, the contraindications/cautions deemed relevant in round 2 were reviewed (Table 2). Participants had to label each of the presented items as either "contraindication" or "caution" or "neither contraindication nor caution" in a closed question format.

Consensus on contraindications was defined a priori if more than $70 \%$ of participating experts labeled the respective item as contraindication. Consensus on cautions was 
predefined if more than $70 \%$ of participating experts labeled the line item as contraindication or caution. All line items that did not meet these criteria were predefined as neither contraindication nor caution.

Additionally, participants were asked to indicate the estimated impact/severity of an adverse event caused by the respective contraindication/caution. In medicine and health sciences, quality of life has been used as a measure to identify the range of problems that can affect patients and to help them anticipate and understand the consequences of a condition and its treatment [40]. Therefore, the estimated impact/severity of potential adverse events by the degree to which the quality of life would be influenced by someone experiencing the respective contraindication/caution on a 7-point Likert scale was measured (1 equaling very bad quality of life, 7 equaling excellent quality of life).

Furthermore, participants were given the option to argue against the drop of items after round 2. In an open format text field, experts could outline as to why they would consider such items as contraindication or caution.

The results of round 3 were predefined as end point of the Delphi process.

The outputs, planned timeframes, items to be dropped and requirements for consensus of each round are depicted in Figure 4.

\section{PRE-PHASE}

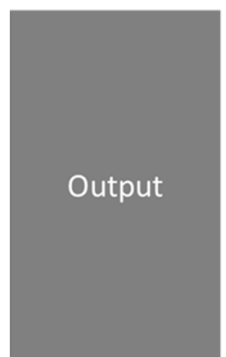

Timeframe 3 to 4 weeks
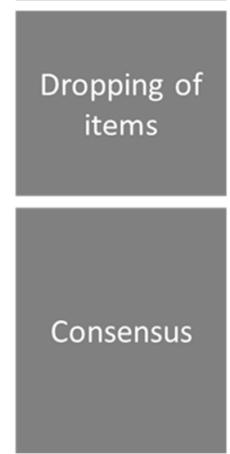

DELPHI ROUND 1

- Comprehensive list of
possible contra-
indications / cautions
with reasons
- First indication of
relevance for the
contraindications and
cautions obtained from
the literature

- 1 month (response within 10 days)

- No items will be dropped
in round 1

DELPHI ROUND 2

- List of contraindications /
cautions that experts
agree with at least
moderately

- 1 month (response within 10 days)

- Items that will not be
scored 5 or higher on scored 5 or higher on a $6-$
point Likert scale by at least $75 \%$ of the participants will be dropped

- Only contraindications/ cautions that at least $75 \%$ of participating experts agree with at least moderately (Likert score 5 or more) are further being considered for round 3
DELPHI ROUND 3

- Final list of contraindications and cautions

- 1 month (response within 10 days)

- No items will be dropped in round 3

- Veto option for items that were dropped in round 2

- Consensus on "contraindications" will be reached if more than $70 \%$ of the participating experts label the respective contraindication as such

Figure 4. Outputs, planned timeframes, items to be dropped and requirements for consensus of each Delphi process round.

\subsubsection{Data Processing}

Study data were collected using an electronic questionnaire (SurveyMonkey Europe UC, Dublin, Ireland) between March and May 2021. After seven and ten workdays, reminders were sent to participants in each round. Data collection was carried out anonymously [32].

Descriptive statistical analyses were performed to evaluate the closed-question Likert scale. All quantitative statistical analyses were made with Excel (Microsoft Corporation, Redmond, WA, USA). Open text responses were compiled by the Study Steering Group. 


\section{Results}

Forty-eight experts volunteered to participate. Responses were received from 43 participants in Delphi process round 1 (10.9\% response rate of all identified experts; $89.6 \%$ response rate of experts who provided consent), from 41 participants in Delphi process round $2(10.4 \% / 85.4 \%$ response rate), and from 37 participants $(9.3 \% / 77.1 \%$ response rate) in Delphi process round 3, respectively. Experts were mainly sports scientists $(n=21$ in round 3$)$ followed by physiotherapists $(n=6)$ and medical professionals $(n=5)$. The nationalities represented among these included USA (9), Germany (8), United Kingdom (7), Spain (6), France (2), as well as 1 person each from Australia, Austria, Brazil, Canada, Greece, Ireland, Italy, Japan, Poland, Taiwan, and Turkey. An overview of the characteristics of study participants for each round is depicted in Figure 5.

\begin{tabular}{|c|c|c|}
\hline \multirow{2}{*}{$\begin{array}{l}\text { Professional } \\
\text { background / area } \\
\text { of research }\end{array}$} & \multicolumn{2}{|c|}{ Delphi process round 1} \\
\hline & $\begin{array}{l}\text { Number of } \\
\text { participants }(n)\end{array}$ & $\begin{array}{l}\text { Thereof first } \\
\text { authors }(n)\end{array}$ \\
\hline Sports Science & 22 & 15 \\
\hline Physiotherapy & 11 & 7 \\
\hline Medicine / Physician & 5 & 4 \\
\hline Other & 5 & 1 \\
\hline Overall & 43 & 27 \\
\hline $\begin{array}{l}\text { Specification of } \\
\text { "other" }\end{array}$ & $\begin{array}{ll}\text { - } & \text { Connective tis } \\
\text { - } & \text { Assistant Prof } \\
\text { Graduate Spo } \\
\text { litator / Streng } \\
\text { ditioning Coac } \\
\text { - } \quad \text { Neurophysiolo } \\
\text { - } \quad \text { Exercise Phys } \\
\text { - Sport Rehabil }\end{array}$ & $\begin{array}{l}\text { sue research } \\
\text { essor / } \\
\text { t Rehabi- } \\
\text { h \& Con- } \\
\text { h } \\
\text { gy } \\
\text { iology } \\
\text { tator }\end{array}$ \\
\hline
\end{tabular}

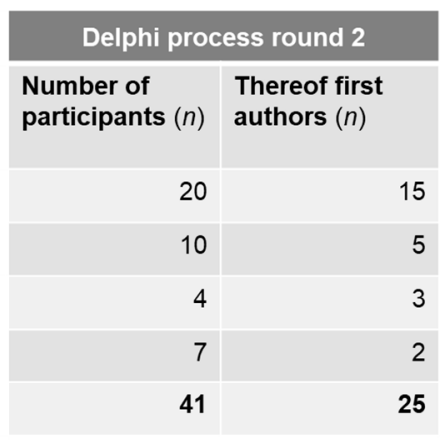

Exercise Science

- Graduate Sport Rehabilitator

- Sport Rehabilitator

- Manual therapy research

- Neurophysiology

- Exercise Physiology / Strength \& Conditioning

- $\quad$ Strength \& Conditioning

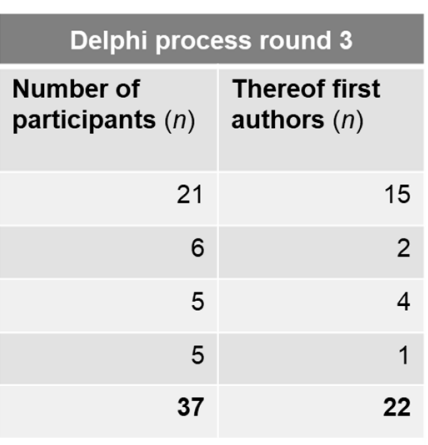

Sport Rehabilitator

- Graduate Sport Rehabilitator

- Neurophysiology

- Research and teaching related to fascia

- Strength \& Conditioning

Figure 5. Overview of participant characteristics.

After Delphi process round 1, the Study Steering Group agreed that participant comments supported to subdivide one existing statement and add 6 conditions (Table 2). A total of 38 conditions were submitted to round 2. After round 2, consensus was achieved for three conditions: local tissue inflammation/open wounds $(85.0 \%$ percentage of experts rating agree/strongly agree), bone fracture or myositis ossificans ( $82.5 \%)$, deep vein thrombosis or osteomyelitis (82.5\%). After round 2, the Study Steering Group discussed and agreed to subdivide the three conditions, thus, a total of 6 conditions were taken into round 3 (Table 2).

In round 3, consensus on contraindications of foam rolling was reached for open wounds $(73.0 \%$ percentage agreement; percentage of experts rating the condition as contraindication) and bone fractures $(83.8 \%)$. Consensus on cautions was achieved for local tissue inflammation, myositis ossificans, deep vein thrombosis, and osteomyelitis, with very high percentage agreement (percentage of experts rating the condition as contraindication or caution) ranging from $91.9 \%$ to $97.3 \%$. Table 3 provides an overview of participants' answers in round 3.

Participants indicated the highest estimated impact/severity of an adverse event caused by contraindication/cautions for bone fractures, deep vein thrombosis, and osteomyelitis represented by the highest ratings for very bad quality of living (QoL) for these conditions. Figure 6 depicts the detailed answers of participants on estimated impact/severity in round 3 . 
Table 3. Delphi process round 3 responses. Figures highlighted in grey met the a priori defined criteria for contraindications/cautions.

\begin{tabular}{|c|c|c|c|c|c|c|c|c|c|c|}
\hline & \multicolumn{2}{|c|}{ Contraindication } & \multicolumn{2}{|c|}{ Caution } & \multicolumn{2}{|c|}{$\begin{array}{c}\text { Neither } \\
\text { Contraindication } \\
\text { nor Caution }\end{array}$} & \multicolumn{3}{|c|}{$\begin{array}{l}\text { Contraindication } \\
\quad+\text { Caution }\end{array}$} & \multirow[t]{2}{*}{$\begin{array}{l}\text { Result According } \\
\text { to Valuation Logic }\end{array}$} \\
\hline & $n$ & $\%$ & $n$ & $\%$ & $n$ & $\%$ & $n$ & $\%$ & Sum & \\
\hline $\begin{array}{c}\text { Local tissue } \\
\text { inflammation }\end{array}$ & 15 & 41 & 21 & 57 & 1 & 3 & 36 & 97 & 37 & Caution \\
\hline Open wounds & 27 & 73 & 8 & 22 & 2 & 5 & 35 & 95 & 37 & Contraindication \\
\hline Bone fracture & 31 & 84 & 4 & 11 & 2 & 5 & 35 & 95 & 37 & Contraindication \\
\hline $\begin{array}{l}\text { Myositis } \\
\text { ossificans }\end{array}$ & 20 & 54 & 14 & 38 & 3 & 8 & 34 & 92 & 37 & Caution \\
\hline $\begin{array}{l}\text { Deep vein } \\
\text { thrombosis }\end{array}$ & 24 & 65 & 12 & 32 & 1 & 3 & 36 & 97 & 37 & Caution \\
\hline Osteomyelitis & 22 & 61 & 12 & 33 & 2 & 6 & 34 & 94 & 36 & Caution \\
\hline
\end{tabular}

\begin{tabular}{|c|c|c|c|c|c|c|c|c|c|c|c|c|c|c|}
\hline \multirow[b]{2}{*}{ Local tissue inflammation } & \multicolumn{2}{|c|}{$\begin{array}{c}1 \text { very bad } \\
\text { QoL }\end{array}$} & \multicolumn{2}{|c|}{2} & \multicolumn{2}{|c|}{3} & \multicolumn{2}{|c|}{4} & \multicolumn{2}{|c|}{5} & \multicolumn{2}{|c|}{6} & \multicolumn{2}{|c|}{$\begin{array}{c}7 \text { excellent } \\
\text { QoL }\end{array}$} \\
\hline & $n=1$ & $2.7 \%$ & $n=3$ & $8.1 \%$ & $n=18$ & $48.7 \%$ & $n=6$ & $16.2 \%$ & $n=7$ & $18.9 \%$ & $n=2$ & $5.4 \%$ & $n=0$ & $0.0 \%$ \\
\hline Open wounds & $n=5$ & $13.5 \%$ & $n=12$ & $32.4 \%$ & $n=10$ & $27.0 \%$ & $n=4$ & $10.8 \%$ & $n=3$ & $8.1 \%$ & $n=3$ & $8.1 \%$ & $n=0$ & $0.0 \%$ \\
\hline Bone fracture & $n=14$ & $38.9 \%$ & $n=15$ & $41.7 \%$ & $n=4$ & $11.1 \%$ & $n=2$ & $5.6 \%$ & $n=0$ & $0 \%$ & $n=1$ & $2.8 \%$ & $n=0$ & $0.0 \%$ \\
\hline Myositis ossificans & $n=3$ & $8.1 \%$ & $n=9$ & $24.3 \%$ & $n=13$ & $35.1 \%$ & $n=8$ & $21.6 \%$ & $n=4$ & $10.8 \%$ & $n=0$ & $0.0 \%$ & $n=0$ & $0.0 \%$ \\
\hline Deep vein thrombosis & $n=10$ & $27.0 \%$ & $n=12$ & $32.4 \%$ & $n=8$ & $21.6 \%$ & $n=7$ & $18.9 \%$ & $n=0$ & $0.0 \%$ & $n=0$ & $0.0 \%$ & $n=0$ & $0.0 \%$ \\
\hline Osteomyelitis & $n=10$ & $27.0 \%$ & $n=7$ & $18.9 \%$ & $n=11$ & $29.7 \%$ & $n=9$ & $24.3 \%$ & $n=0$ & $0.0 \%$ & $n=0$ & $0.0 \%$ & $n=0$ & $0.0 \%$ \\
\hline
\end{tabular}

Figure 6. Estimated impact/severity of an adverse event (defined as quality of living; QoL) caused by contraindications/cautions.

In round 3, three participants made use of the option to argue against the dropping of items after round 2. An overview of their responses is given in Figure 7.

When conducting sub-analyses for the different professional backgrounds (i.e., sports science, physiotherapy, medicine/physicians, other), slight differences in opinion emerged. After Delphi process round 2, several conditions would have moved on to Delphi process round 3 according to the evaluation of medical professionals/physicians (skin rashes, scrapes, blisters, hematoma, bruises), sports scientists (skin rashes, scrapes, blisters), and professionals from other backgrounds (uncontrolled hypertension, bleeding disorders). Furthermore, after Delphi process round 3, consensus on contraindications was assessed slightly differently among the professional groups (medicine/physicians: local tissue inflammation, bone fracture, osteomyelitis; sports scientists: bone fracture; physiotherapists: open wounds, bone fracture, deep vein thrombosis, osteomyelitis; other backgrounds: open wounds, bone fractures, myositis ossificans, deep vein thrombosis). Figure $8 \mathrm{a}, \mathrm{b}$ provide detailed information about participants' responses sorted by professional background across Delphi process rounds 1 and 2. 
Participant A, Sports Scientist, First Author

\begin{tabular}{|c|c|}
\hline Hypertension - varicose veins & $\begin{array}{l}\text { It is often claimed that FR leads to the decrease of stiffness of arteries. This is true in the acute case, medium - and long term the opposite } \\
\text { is true. Venous valves are very sensitive to mechanical stress, especially if they are pre-damaged. This is an absolute contraindication! }\end{array}$ \\
\hline Osteoporosis - Osteopenia & Further clinical pictures are absolute contraindications depending on their severity, especially in the back and hip joint area. \\
\hline $\begin{array}{l}\text { Diabetes - Metabolic } \\
\text { syndrome }\end{array}$ & If associated with neuropathy, chronic damage to nerve pathways is possible. Diabetes is part of metabolic syndrome \\
\hline $\begin{array}{l}\text { Blood thinners and bleeding } \\
\text { disorders }\end{array}$ & In hemophilia, even small mechanical loads can lead to bleeding, as can high doses of blood-thinning medications. \\
\hline $\begin{array}{l}\text { Lymphedema \& acute } \\
\text { systemic infection }\end{array}$ & $\begin{array}{l}\text { Lymphatic vessels are extremely sensitive to mechanical influences. Lymph nodes can be mechanically squeezed when subjected to } \\
\text { mechanical stress and the bacteria/viruses can be released.... }\end{array}$ \\
\hline
\end{tabular}

Participant B, Sports Scientist, First Author

Severe pain

Pain is a body alarm system, so it's important not to ignore it

Participant C, Medical Professional/Physician, Co-Author

Anticoagulant

Risk of internal haemorrage

Figure 7. Arguments against dropping of items after Delphi process round 2.

\section{a - Round 1}

Bone fracture or myositis ossificans Skin rash, open wounds, blisters, local tissue inflammation Deep vein thrombosis or osteomyelitis

Bleeding disorders (e.g. Hemophilia)

Extreme discomfort felt by patient Inability to position body or perform foam rolling

Peripheral vascular insufficiency or disease Acute infection (viral or bacterial), fever, or contagious condition Medications that may alter a person's sensation Varicose veins Recent injury or surgery Use of blood thinners or medications that modify touch/pressure sensitivity Pregnancy (without consultation by MD) Bony prominences / regions Neurologic conditions resulting in loss or altered sensation (e.g. Multiple sclerosis) Osteoporosis Sensitivity to pressure

Abnormal sensations (e.g. numbness) Acute or severe cardiac, liver, or kidney disease Cancer or malignancy Connective tissue disorders (e.g. Marfan syndrome) Severe scoliosis or spinal deformity Hypertension (uncontrolled) Osteopenia Diabetes

Chronic pain conditions (e.g. Rheumatoid arthritis) Systemic conditions (e.g. metabolic syndrome/syndrome X) Scoliosis or spinal deformity Pregnancy (after consultation by MD)

Young children, older individuals Hypertension (with consolation by MD and controlled)

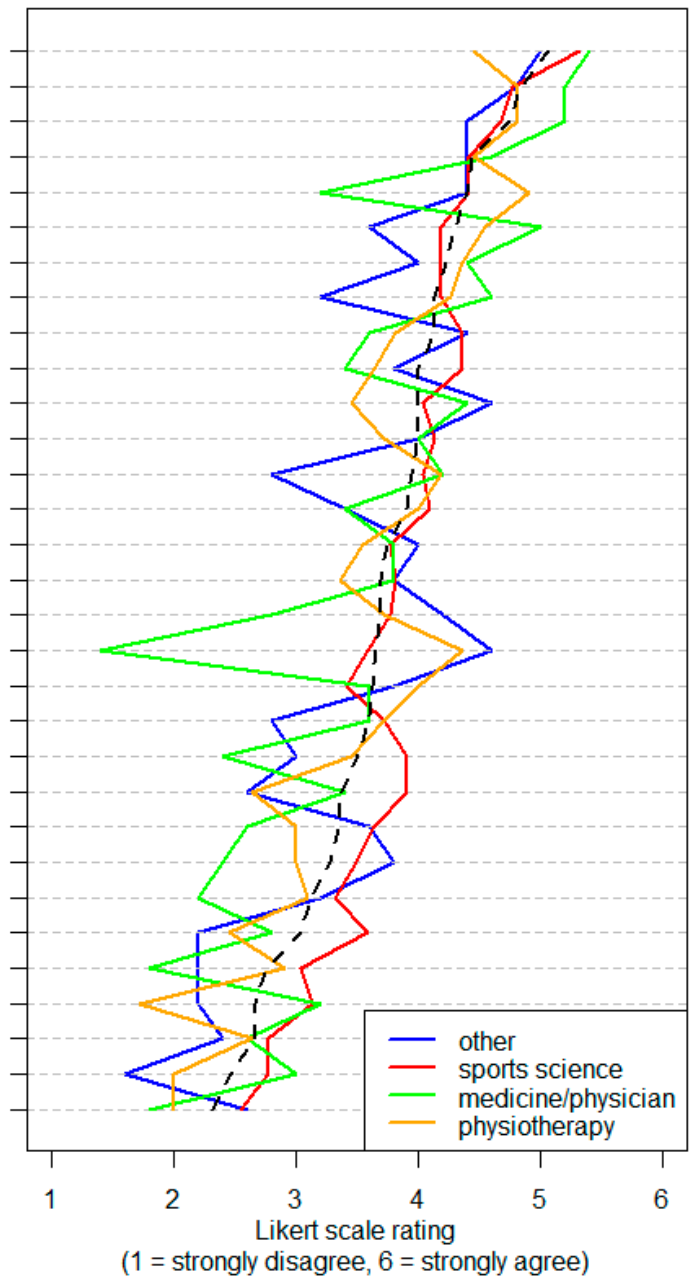

Figure 8. Cont. 


\section{b - Round 2}

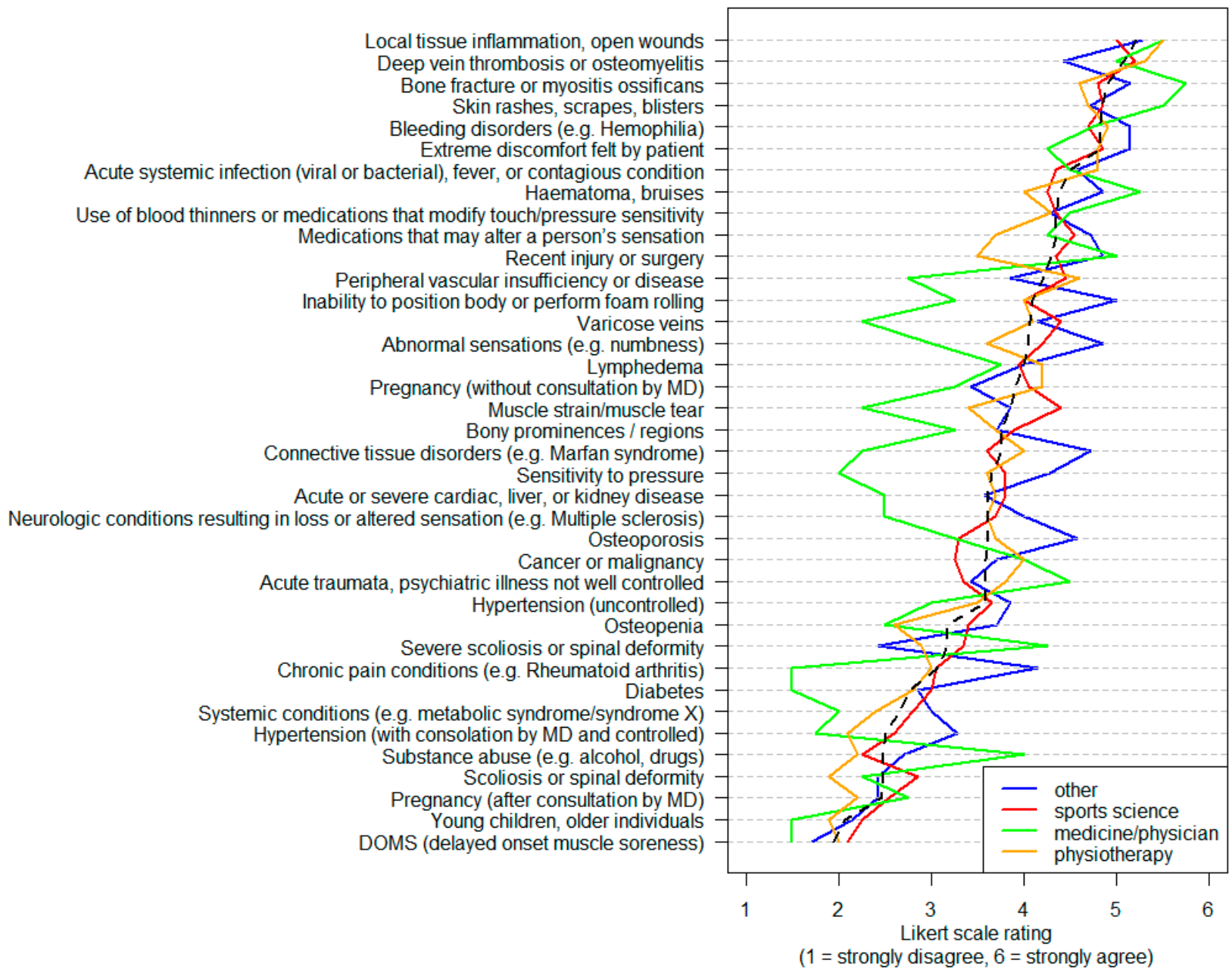

Figure 8. Participants' responses in Delphi according to professional background in round 1 (a) and round 2 (b). Note: The black line indicates the mean.

\section{Discussion}

This is the first study to gain international expert consensus on contraindications and cautions of foam rolling. The agreement for the final set of conditions was high (with at least $73 \%$ agreement) for contraindications and very high (with at least $92 \%$ agreement) for cautions. Our results provide implications for professionals in sports, physical therapy, and medicine: researchers, coaches, and clinicians should consider potential risks of foam rolling in future research and clinical practice.

Our main finding was that bone fractures and open wounds were classified as contraindications of foam rolling by the panel experts, while local tissue inflammation, myositis ossificans, osteomyelitis and deep vein thrombosis were categorized as precautions.

When applying foam rolling to musculoskeletal tissues, mechanical forces are administered. Similarly, the introduction of mechanical forces is used by clinicians and coaches to promote tissue healing, as musculoskeletal tissues respond and adapt to their mechanical environment [41]. As the specific effects of foam rolling on underlying mechanistic (as well as neural) mechanisms are still unclear [8], one can draw information from the neighboring fields of physical and manual therapy in order to evaluate the contraindications and cautions identified by panel experts. 


\subsection{Open Wounds and Local Tissue Inflammation}

Open wounds range from abrasions, minor skin incision or tears to wounds with extensive tissue damage or loss. Wound healing includes sequential, yet overlapping phases, including hemostasis, inflammation, proliferation, and remodeling [42,43]. Despite a great body of literature, many underlying pathophysiological processes of wound healing are still unknown [44]. It appears evident that the healing process in the initial phases of hemostasis should not be disturbed through mechanical disruption (as would be the case when foam rolling is applied). A more complicated picture emerges once the initial wound closure is complete and the subsequent inflammatory processes commence. When looking to evaluate the effect of myofascial release therapies on wound healing and inflammatory processes, recent studies suggest that soft tissue inflammation may be reduced by modalities such as soft tissue massage [41]. A range of in vitro studies has looked at fibroblasts' response to mechanical forces, i.e., myofascial release techniques. Findings of these studies included reduction of wound size, increased collagen density, and improved cell deposition at the wound site by means of fibroblast proliferation [45,46]. Another in vitro study showed that therapeutic soft tissue massage may reduce pro-inflammatory cytokines such as IL-6 and IL-8 [47]. However, the effect of myofascial release techniques on certain inflammatory mediators seems to be dose-dependent: by varying the parameters of the applied biomechanical stimuli, myofascial release can be both an activator and an inhibitor of fibroblast-inflammation [48]. While these in vitro findings are promising evidence in favor of myofascial release techniques in general and consequently for modalities such as foam rolling in particular, they cannot easily be correlated with clinical outcomes. In vivo studies on human wound healing are needed to improve our understanding of the pathogenesis of wound healing as well as the influence and dose-response relationships of myofascial modalities such as foam rolling on its underlying molecular processes.

\subsection{Bone Fractures}

The healing process of a bone fracture progresses from an initial inflammatory phase ( $0-3$ days after injury) to the formation of a soft and then a hard callus ( 4 days to months after injury), and finally to bony remodeling (months to years after an injury) [42,49]. During initial callus formation, maximal possible rigidity (i.e., stabilization) is desirable. Once the mineralized callus is formed, the application of mechanical strain can influence bone healing positively. According to experimental data, the optimal mechanical strain should range between 100 and 2000 microstrain (during normal walking, bones experience strains in the range of 1000 microstrain). When the applied strain exceeds the allowable strain, hard callus will not form. Clinical guidelines entail recommendations for progressive load bearing [50]. However, as there is no methodology or device to reliably guide or apply the ideal amount of strain, and as further parameters such as type and location of bone, age, and hormonal status are to be considered individually, no absolute parameters of strain magnitudes and frequencies exist [42,50]. Apart from the lack of absolute strain recommendations for all patients, measuring the definite strain applied through foam rolling is not possible with current foam rolling tools. Accordingly, the application of foam rolling may well impair fracture healing by applying too much strain. Panelists ${ }^{\prime}$ categorization of bone fractures as contraindications therefore presents as plausible and reasonable. Future studies are needed to provide answers on absolute strain parameters and lead to the development of tools that allow for targeted load application.

\subsection{Deep Vein Thrombosis}

Deep vein thrombosis and pulmonary embolism are collectively referred to as venous thromboembolism and are associated with substantial morbidity and mortality. Strong risk factors include surgery, immobilization, and cancer. Anticoagulants constitute the primary approach to therapy $[51,52]$.

The application of mechanical forces through modalities such as manual therapy or massage can potentially mechanically dislodge a thrombus, as reported by various case 
reports [53-56]. The most recent of these case studies reported that leg massage during pregnancy with unrecognized deep vein thrombosis can dislodge thrombi, leading to a life-threatening pulmonary embolism. Massage of the lower extremity in cases of deep venous thrombosis is therefore contraindicated according to the authors [56]. Consequently, as foam rolling potentially leads to similar mechanical forces as massage, the panelists evaluation of deep vein thrombosis as a contraindication of foam rolling is in line with the above mentioned case reports and studies.

As many individuals with a first episode of venous thromboembolism will have a recurring event [57], it remains unclear whether patients with a history of deep vein thrombosis should consider modalities like foam rolling with progression of time, as current therapy guidelines do not include respective recommendations [58]. Future studies will need to gauge the risk of treatments such as foam rolling for former patients and populations at risk.

\subsection{Osteomyelitis}

Osteomyelitis is an inflammation of bone tissue caused by an infectious agent. About half of all cases in adult patients are post-traumatic, meaning that the disease occurs at the wound site after surgery, open fractures, or other injuries. In acute post-traumatic as well as in chronic osteomyelitis, surgery with debridement and antimicrobial/antibiotic therapy are recommended. Drainage and wound closure are further important steps of infection control $[59,60]$. The use of external fixators, sometimes in combination of negative pressure closed drainage is another example of the condition's clinical management [60]. Given the nature of the disease and its treatment, experts' evaluation of osteomyelitis as a contraindication of foam rolling presents as apparent and logical.

\subsection{Myositis Ossificans}

Myositis ossificans is a benign, ossifying soft-tissue mass, typically occurring within skeletal muscle [61]. Symptoms include localized pain and swelling as well as loss of range of motion. The exact pathophysiology of the condition is still poorly understood [61]. The guiding principle in treatment of myositis ossificans is to minimize symptoms and to restore function. Any modalities that may increase the risk for bleeding are to be avoided, particularly in the early phases of the condition. Other modalities which have been described to improve some muscular contusions have been described to exacerbate symptoms if performed too soon or aggressively [61,62]. Avoiding pressure through foam rolling in order to avoid further hematoma or contusions is in line with these recommendations. Future research is needed to describe and quantify the specific effects of foam rolling on this condition.

\subsection{Limitations}

Although the Delphi process resulted in high agreement among academic experts, there are a few limitations. While our results represent participants' perception and awareness about contraindications and cautions of foam rolling, they do not indicate the actual medical risks of foam rolling. Further evaluations by medical professionals as well as the collection of clinical data are needed in the future to assess the risks of foam rolling and to generate guidance for different applications and professional backgrounds. Our results may indicate potential directions and avenues for future research and can assist in selecting the scope for future controlled studies.

Although a diverse range of professional backgrounds among panelists was represented, a large proportion (56.8\% in round 3 ) of participants had a sports science background. This mirrors our approach of recruitment, as the current majority of the foam rolling literature originates from the realm of sports science.

Further, the varieties in answers between professional groups indicate that the awareness for contraindications and cautions of foam rolling may differ in various settings. This may be caused by diverse experiences and observations by the experts. Within this context 
it is important to note that a clear definition of foam rolling regarding applied forces, velocity, and duration [63-65] is still missing. Furthermore, various kinds of foam rolling tools-different surface types [66], densities [67,68], and incorporation of vibration elements [69-71] —are currently being discussed in the literature. Experiences with different characteristics of these parameters may have influenced experts' ratings and assessments.

\section{Conclusions}

This Delphi study outlines potential contraindications and cautions of foam rolling of which none have been reported within clinical trials yet. Open wounds and bone fractures were classified as contraindications of foam rolling by the panel experts, while local tissue inflammation, deep vein thrombosis, myositis ossificans, and osteomyelitis were categorized as cautions. Future work should develop evidence-based data on contraindications and cautions of foam rolling for different conditions as well as different professional settings.

Author Contributions: Conceptualization: J.F., R.S., K.M.B., C.B., M.W.H.; formal analysis: K.M.B.; investigation: K.M.B., S.T.; methodology: K.M.B., R.S., J.F., C.B., M.W.H., G.S., J.W., C.E., W.K., S.T.; project administration: K.M.B., S.T.; resources: K.M.B., R.S.; supervision: R.S., J.F.; validation: K.M.B., R.S., J.F., C.B., M.W.H., G.S., J.W., C.E., W.K., S.T.; visualization: K.M.B.,C.B.; writing-original draft: K.M.B.; writing-review and editing: K.M.B., R.S., J.F., C.B., M.W.H., G.S., J.W., C.E., W.K., S.T. All authors have read and agreed to the published version of the manuscript.

Funding: The authors received no financial support for the research, authorship and/or publication of this article.

Institutional Review Board Statement: The study was conducted according to the guidelines of the Declaration of Helsinki, and approved by the local Ethics Approval Committee of Diploma University of Applied Sciences, Bad Sooden-Allendorf, Germany (approval number EB 1003).

Informed Consent Statement: Not applicable.

Data Availability Statement: The datasets that will be used and/or analyzed during the current study will be available from the corresponding author on reasonable request.

Conflicts of Interest: R.S. and K.M.B. report funding from the charity association Verein zur Förderung der Faszienforschung e.V. [72]. This funding is not related to the current study. J.F., C.B., J.W., G.S., M.W.H., W.K., S.T. report no competing interests.

\section{References}

1. Beardsley, C.; Škarabot, J. Effects of self-myofascial release: A systematic review. J. Bodyw. Mov. Ther. 2015, 19, 747-758. [CrossRef]

2. Cheatham, S.W.; Kolber, M.J.; Cain, M.; Lee, M. The Effects of Self-Myofascial Release using a Foam Roll or Roller Massager on Joint Range of Motion, Muscle Recovery, and Performance: A Systematic Review. Int. J. Sports Phys. Ther. 2015, 10, 827-838. [PubMed]

3. Schroeder, A.N.; Best, T.M. Is self myofascial release an effective preexercise and recovery strategy? A literature review. Curr. Sports Med. Rep. 2015, 14, 200-208. [CrossRef] [PubMed]

4. Wiewelhove, T.; Doweling, A.; Schneider, C.; Hottenrott, L.; Meyer, T.; Kellmann, M.; Pfeiffer, M.; Ferrauti, A. A Meta-Analysis of the Effects of Foam Rolling on Performance and Recovery. Front. Physiol. 2019, 10, 376. [CrossRef]

5. Altarriba-Bartes, A.; Peña, J.; Vicens-Bordas, J.; Casals, M.; Peirau, X.; Calleja-González, J. The use of recovery strategies by Spanish first division soccer teams: A cross-sectional survey. Physician Sportsmed. 2021, 49, 297-307. [CrossRef] [PubMed]

6. Querido, S.M.; Brito, J.; Figueiredo, P.; Carnide, F.; Vaz, J.R.; Freitas, S.R. Post-Match Recovery Practices in Professional Football: Design, Validity, and Reliability of a New Questionnaire. Front. Sports Act Living 2021, 3, 680799. [CrossRef]

7. Freiwald, J.; Baumgart, C.; Kühnemann, M.; Hoppe, M.W. Foam-Rolling in sport and therapy-Potential benefits and risks: Part 1-Definitions, anatomy, physiology, and biomechanics. Sports Orthop. Traumatol. 2016, 32, 258-266. [CrossRef]

8. Behm, D.G.; Wilke, J. Do Self-Myofascial Release Devices Release Myofascia? Rolling Mechanisms: A Narrative Review. Sports Med. 2019, 49, 1173-1181. [CrossRef] [PubMed]

9. Hendricks, S.; Hill, H.; Hollander, S.D.; Lombard, W.; Parker, R. Effects of foam rolling on performance and recovery: A systematic review of the literature to guide practitioners on the use of foam rolling. J. Bodyw. Mov. Ther. 2020, 24, 151-174. [CrossRef] [PubMed]

10. Skinner, B.; Moss, R.; Hammond, L. A systematic review and meta-analysis of the effects of foam rolling on range of motion, recovery and markers of athletic performance. J. Bodyw. Mov. Ther. 2020, 24, 105-122. [CrossRef] [PubMed] 
11. Wilke, J.; Muller, A.L.; Giesche, F.; Power, G.; Ahmedi, H.; Behm, D.G. Acute Effects of Foam Rolling on Range of Motion in Healthy Adults: A Systematic Review with Multilevel Meta-analysis. Sports Med. 2020, 50, 387-402. [CrossRef] [PubMed]

12. Freiwald, J.; Baumgart, C.; Kühnemann, M.; Hoppe, M.W. Foam-Rolling in sport and therapy-Potential benefits and risks: Part 2-Positive and adverse effects on athletic performance. Sports Orthop. Traumatol. 2016, 32, 267-275. [CrossRef]

13. Cheatham, S.W.; Stull, K.R. Roller Massage: A Commentary on Clinical Standards and Survey of Physical Therapy ProfessionalsPart 1. Int. J. Sports Phys. Ther. 2018, 13, 763-772. [CrossRef]

14. Henschke, N.; Maher, C.G.; Ostelo, R.W.; de Vet, H.C.; Macaskill, P.; Irwig, L. Red flags to screen for malignancy in patients with low-back pain. Cochrane Database Syst. Rev. 2013, 2, CD008686. [CrossRef]

15. Verhagen, A.P.; Downie, A.; Popal, N.; Maher, C.; Koes, B.W. Red flags presented in current low back pain guidelines: A review. Eur. Spine J. 2016, 25, 2788-2802. [CrossRef]

16. Zhu, Y.; Wang, Z.; Zhou, Y.; Onoda, K.; Maruyama, H.; Hu, C.; Liu, Z. Summary of respiratory rehabilitation and physical therapy guidelines for patients with COVID-19 based on recommendations of World Confederation for Physical Therapy and National Association of Physical Therapy. J. Phys. Ther. Sci. 2020, 32, 545-549. [CrossRef]

17. American College of Sports Medicine. ACSM's Health-Related Physical Fitness Assessment Manual; Wolters Kluwer Health/Lippincott Williams \& Wilkins: Philadelphia, PA, USA, 2014; pp. 135-158.

18. Ernst, E. The safety of massage therapy. Rheumatology 2003, 42, 1101-1106. [CrossRef] [PubMed]

19. Batavia, M. Contraindications for therapeutic massage: Do sources agree? J. Bodyw. Mov. Ther. 2004, 8, 48-57. [CrossRef]

20. Nielsen, A.; Kligler, B.; Koll, B.S. Safety protocols for gua sha (press-stroking) and baguan (cupping). Complement. Ther. Med. 2012, 20, 340-344. [CrossRef]

21. McKenney, K.; Elder, A.S.; Elder, C.; Hutchins, A. Myofascial release as a treatment for orthopaedic conditions: A systematic review. J. Athl. Train. 2013, 48, 522-527. [CrossRef]

22. Yin, P.; Gao, N.; Wu, J.; Litscher, G.; Xu, S. Adverse events of massage therapy in pain-related conditions: A systematic review. Evid. Based Complement. Altern. Med. 2014, 2014, 480956. [CrossRef] [PubMed]

23. Westman, K.F.; Blaisdell, C. Many Benefits, Little Risk: The Use of Massage in Nursing Practice. Am. J. Nurs. 2016, 116, 34-39, quiz 40-31. [CrossRef]

24. Laimi, K.; Makila, A.; Barlund, E.; Katajapuu, N.; Oksanen, A.; Seikkula, V.; Karppinen, J.; Saltychev, M. Effectiveness of myofascial release in treatment of chronic musculoskeletal pain: A systematic review. Clin. Rehabil. 2018, 32, 440-450. [CrossRef] [PubMed]

25. Cantrill, J.A.; Sibbald, B.; Buetow, S. The Delphi and nominal group techniques in health services research. Int. J. Pharm. Pract. 1996, 4, 67-74. [CrossRef]

26. Wells, C.; Kolt, G.S.; Marshall, P.; Bialocerkowski, A. Indications, benefits, and risks of Pilates exercise for people with chronic low back pain: A Delphi survey of Pilates-trained physical therapists. Phys. Ther. 2014, 94, 806-817. [CrossRef]

27. Alexiades, N.G.; Shao, B.; Braga, B.P.; Bonfield, C.M.; Brockmeyer, D.L.; Browd, S.R.; DiLuna, M.; Groves, M.L.; Hankinson, T.C.; Jea, A.; et al. Development of best practices in the utilization and implementation of pediatric cervical spine traction: A modified Delphi study. J. Neurosurg. Pediatrics 2021, 27, 649-600. [CrossRef] [PubMed]

28. Robben, E.; Kempeneers, K.; De Groef, A.; Depreitere, B.; Peers, K. Guidelines for Rehabilitation and Return to Play After Cervical Surgery in a General Athletic Population: A Delphi Analysis. Clin. J. Sport Med. 2021, 31, 145-150. [CrossRef]

29. Fish, L.; Busby, D. The Delphi method. In Research Methods in Family Therapy; The Guilford Press: New York, NY, USA, 1996; pp. 469-482.

30. Boulkedid, R.; Abdoul, H.; Loustau, M.; Sibony, O.; Alberti, C. Using and reporting the Delphi method for selecting healthcare quality indicators: A systematic review. PLoS ONE 2011, 6, e20476. [CrossRef] [PubMed]

31. Trevelyan, E.G.; Robinson, P.N. Delphi methodology in health research: How to do it? Eur. J. Integr. Med. 2015, 7, 423-428. [CrossRef]

32. Diamond, I.R.; Grant, R.C.; Feldman, B.M.; Pencharz, P.B.; Ling, S.C.; Moore, A.M.; Wales, P.W. Defining consensus: A systematic review recommends methodologic criteria for reporting of Delphi studies. J. Clin. Epidemiol. 2014, 67, 401-409. [CrossRef]

33. Dirks, M.; Niessen, L.W.; Koudstaal, P.J.; Franke, C.L.; van Oostenbrugge, R.J.; Dippel, D.W. Intravenous thrombolysis in acute ischaemic stroke: From trial exclusion criteria to clinical contraindications. An international Delphi study. J. Neurol. Neurosurg. Psychiatry 2007, 78, 685-689. [CrossRef]

34. Goluchowicz, K.; Blind, K. Identification of future fields of standardisation: An explorative application of the Delphi methodology. Technol. Forecast. Soc. Chang. 2011, 78, 1526-1541. [CrossRef]

35. Rowe, G.; Wright, G. The Delphi technique: Past, present, and future prospects-Introduction to the special issue. Technol. Forecast. Soc. Chang. 2011, 78, 1487-1490. [CrossRef]

36. Schmidt, R.; Lyytinen, K.; Keil, M.; Cule, P. Identifying Software Project Risks: An International Delphi Study. J. Manag. Inf. Syst. 2001, 17, 5-36. [CrossRef]

37. Okoli, C.; Pawlowski, S.D. The Delphi method as a research tool: An example, design considerations and applications. Inf. Manag. 2004, 42, 15-29. [CrossRef]

38. Hasson, F.; Keeney, S. Enhancing rigour in the Delphi technique research. Technol. Forecast. Soc. Chang. 2011, 78, 1695-1704. [CrossRef]

39. Heick, J.; Lazaro, R.T. Differential Diagnosis for Physical Therapists: Screening for Referral, 6th ed.; Elsevier: St. Louis, MO, USA, 2018. 
40. Haraldstad, K.; Wahl, A.; Andenaes, R.; Andersen, J.R.; Andersen, M.H.; Beisland, E.; Borge, C.R.; Engebretsen, E.; Eisemann, M.; Halvorsrud, L.; et al. A systematic review of quality of life research in medicine and health sciences. Qual. Life Res. 2019, 28, 2641-2650. [CrossRef] [PubMed]

41. Thompson, W.R.; Scott, A.; Loghmani, M.T.; Ward, S.R.; Warden, S.J. Understanding Mechanobiology: Physical Therapists as a Force in Mechanotherapy and Musculoskeletal Regenerative Rehabilitation. Phys. Ther. 2016, 96, 560-569. [CrossRef]

42. Janis, J.E.; Harrison, B. Wound Healing: Part I. Basic Science. Plast. Reconstr. Surg. 2016, 138, 9S-17S. [CrossRef]

43. Wang, P.H.; Huang, B.S.; Horng, H.C.; Yeh, C.C.; Chen, Y.J. Wound healing. J. Chin. Med. Assoc. 2018, 81, 94-101. [CrossRef] [PubMed]

44. Sorg, H.; Tilkorn, D.J.; Hager, S.; Hauser, J.; Mirastschijski, U. Skin Wound Healing: An Update on the Current Knowledge and Concepts. Eur. Surg. Res. 2017, 58, 81-94. [CrossRef] [PubMed]

45. Zein-Hammoud, M.; Standley, P.R. Optimized Modeled Myofascial Release Enhances Wound Healing in 3-Dimensional Bioengineered Tendons: Key Roles for Fibroblast Proliferation and Collagen Remodeling. J. Manip. Physiol. Ther. 2019, 42, 551-564. [CrossRef]

46. Zein-Hammoud, M.; Standley, P.R. Modeled Osteopathic Manipulative Treatments: A Review of Their in Vitro Effects on Fibroblast Tissue Preparations. J. Am. Osteopath. Assoc. 2015, 115, 490-502. [CrossRef]

47. Anloague, A.; Mahoney, A.; Ogunbekun, O.; Hiland, T.A.; Thompson, W.R.; Larsen, B.; Loghmani, M.T.; Hum, J.M.; Lowery, J.W. Mechanical stimulation of human dermal fibroblasts regulates pro-inflammatory cytokines: Potential insight into soft tissue manual therapies. BMC Res. Notes 2020, 13, 400. [CrossRef] [PubMed]

48. Cao, T.V.; Hicks, M.R.; Campbell, D.; Standley, P.R. Dosed myofascial release in three-dimensional bioengineered tendons: Effects on human fibroblast hyperplasia, hypertrophy, and cytokine secretion. J. Manip. Physiol. Ther. 2013, 36, 513-521. [CrossRef] [PubMed]

49. Kugelmass, N.; Berg, R.N. Ossification: I. Callus Formation and Calcification. Am. J. Dis. Child. 1931, 41, 236-248. [CrossRef]

50. Mavcic, B.; Antolic, V. Optimal mechanical environment of the healing bone fracture/osteotomy. Int. Orthop. 2012, 36, 689-695. [CrossRef]

51. Di Nisio, M.; van Es, N.; Büller, H.R. Deep vein thrombosis and pulmonary embolism. Lancet 2016, 388, 3060-3073. [CrossRef]

52. Streiff, M.B.; Agnelli, G.; Connors, J.M.; Crowther, M.; Eichinger, S.; Lopes, R.; McBane, R.D.; Moll, S.; Ansell, J. Guidance for the treatment of deep vein thrombosis and pulmonary embolism. J. Thromb. Thrombolysis 2016, 41, 32-67. [CrossRef]

53. Jabr, F.I. Massive pulmonary emboli after legs massage. Am. J. Phys. Med. Rehabil. 2007, 86, 691. [CrossRef] [PubMed]

54. Lim, D.C.; Jayanthi, H.K.; Money-Kyrle, A.; Ramrakha, P. Massaging the outcome: An unusual presentation of pulmonary embolism. BMJ Case Rep. 2009, 2009, bcr0120091505. [CrossRef] [PubMed]

55. Behera, C.; Devassy, S.; Mridha, A.R.; Chauhan, M.; Gupta, S.K. Leg massage by mother resulting in fatal pulmonary thromboembolism. Med. Leg. J. 2018, 86, 146-150. [CrossRef]

56. Sutham, K.; Na-Nan, S.; Paiboonsithiwong, S.; Chaksuwat, P.; Tongsong, T. Leg massage during pregnancy with unrecognized deep vein thrombosis could be life threatening: A case report. BMC Pregnancy Childbirth 2020, 20, 237. [CrossRef]

57. Goldhaber, S.Z.; Bounameaux, H. Pulmonary embolism and deep vein thrombosis. Lancet 2012, 379, 1835-1846. [CrossRef]

58. Wilbur, J.; Shian, B. Deep Venous Thrombosis and Pulmonary Embolism: Current Therapy. Am. Fam. Physician 2017, 95, 295-302. [PubMed]

59. Lima, A.L.; Oliveira, P.R.; Carvalho, V.C.; Cimerman, S.; Savio, E. Diretrizes Panamericanas para el Tratamiento de las Osteomielitis e Infecciones de Tejidos Blandos, G. Recommendations for the treatment of osteomyelitis. Braz. J. Infect. Dis. 2014, 18, 526-534. [CrossRef] [PubMed]

60. Yang, J.; Yao, J.L.; Wu, Z.Q.; Zeng, D.L.; Zheng, L.Y.; Chen, D.; Guo, Z.D.; Peng, L. Current opinions on the mechanism, classification, imaging diagnosis and treatment of post-traumatic osteomyelitis. Chin. J. Traumatol. 2021. in Press. [CrossRef] [PubMed]

61. Devilbiss, Z.; Hess, M.; Ho, G.W.K. Myositis Ossificans in Sport: A Review. Curr. Sports Med. Rep. 2018, 17, 290-295. [CrossRef] [PubMed]

62. Jarvinen, T.A.; Jarvinen, T.L.; Kaariainen, M.; Aarimaa, V.; Vaittinen, S.; Kalimo, H.; Jarvinen, M. Muscle injuries: Optimising recovery. Best Pract. Res. Clin. Rheumatol. 2007, 21, 317-331. [CrossRef] [PubMed]

63. Grabow, L.; Young, J.D.; Alcock, L.R.; Quigley, P.J.; Byrne, J.M.; Granacher, U.; Škarabot, J.; Behm, D.G. Higher Quadriceps Roller Massage Forces Do Not Amplify Range-of-Motion Increases nor Impair Strength and Jump Performance. J. Strength Cond. Res. 2018, 32, 3059-3069. [CrossRef] [PubMed]

64. Hughes, G.A.; Ramer, L.M. Duration of Myofascial Rolling for Optimal Recovery, Range of Motion, and Performance: A Systematic Review of the Literature. Int. J. Sports Phys. Ther. 2019, 14, 845-859. [CrossRef] [PubMed]

65. Wilke, J.; Niemeyer, P.; Niederer, D.; Schleip, R.; Banzer, W. Influence of Foam Rolling Velocity on Knee Range of Motion and Tissue Stiffness: A Randomized, Controlled Crossover Trial. J. Sport Rehabil. 2019, 28, 711-715. [CrossRef] [PubMed]

66. Cheatham, S.W.; Stull, K.R. Roller massage: Comparison of three different surface type pattern foam rollers on passive knee range of motion and pain perception. J. Bodyw. Mov. Ther. 2019, 23, 555-560. [CrossRef]

67. Cheatham, S.W.; Stull, K.R. Comparison of Three Different Density Type Foam Rollers on Knee Range of Motion and Pressure Pain Threshold: A Randomized Controlled Trial. Int. J. Sports Phys. Ther. 2018, 13, 474-482. [CrossRef] 
68. Kim, Y.; Hong, Y.; Park, H.S. A soft massage tool is advantageous for compressing deep soft tissue with low muscle tension: Therapeutic evidence for self-myofascial release. Complement. Ther. Med. 2019, 43, 312-318. [CrossRef] [PubMed]

69. Cheatham, S.W.; Stull, K.R.; Kolber, M.J. Comparison of a Vibration Roller and a Nonvibration Roller Intervention on Knee Range of Motion and Pressure Pain Threshold: A Randomized Controlled Trial. J. Sport Rehabil. 2019, 28, 39-45. [CrossRef] [PubMed]

70. Lim, J.H.; Park, C.B. The immediate effects of foam roller with vibration on hamstring flexibility and jump performance in healthy adults. J. Exerc. Rehabil. 2019, 15, 50-54. [CrossRef] [PubMed]

71. Romero-Moraleda, B.; González-García, J.; Cuéllar-Rayo, Á.; Balsalobre-Fernández, C.; Muñoz-García, D.; Morencos, E. Effects of Vibration and Non-Vibration Foam Rolling on Recovery after Exercise with Induced Muscle Damage. J. Sports Sci. Med. 2019, 18, 172-180. [PubMed]

72. Available online: www.faszienforschung.de (accessed on 9 September 2021). 